\title{
The Integration of Islamic Law Toward Anti-Corruption Education in Indonesia
}

\author{
Dr. H. Nur Solikin, S.Ag., M.H
}

State Islamic Institute of Jember, East Java Indonesia

Received: 02 Dec 2020; Received in revised form: 03 Feb 2021; Accepted: 16 Feb 2021; Available online: 14 Mar 2021 (C)2021 The Author(s). Published by Infogain Publication. This is an open access article under the CC BY license (https://creativecommons.org/licenses/by/4.0/).

\begin{abstract}
This research departs from academic anxiety that so far anti-corruption education materials in Indonesia only contain positive legal coverage. In addition, the definition of corruption in the existing anticorruption education material is still very limited, namely detrimental to state finances. This research answers how corruption is in Islamic law, how about anti-corruption education materials in Indonesia, and how the concept of integration of Islamic law in anti-corruption education in Indonesia. The results of this study are as follows: first, corruption in Islamic law is understood as including façade deeds that destroy the order of life, and the perpetrator is categorized as committing a major sin. Islam views corruption as a criminal act (Jarimah) which in fiqh jinayah includes elements that cause others to suffer losses. The forms of corruption in Islam include: al-ghulul, al-rishwah, al-ghașb, al-khiyanah, al-sariqah, al-hirabah, almax, and al-ikhtilas. Second, anti-corruption education is a conscious and planned effort to realize a critical teaching and learning process. Anti-corruption education material should not be limited to transfer of knowledge (cognitive), but emphasizes efforts to form character (affective) and moral awareness (morality consciousness) in fighting (psychomotor) against corruption, because it is substantially against the principle of justice (al- 'is), accountability (al-amanah), and responsibility.
\end{abstract}

Keywords-Integration, Islamic Law, Anti-Corruption Education.

\section{PRELIMINARY}

Corruption in Indonesia is a problem that paralyzes the progress of the nation. ${ }^{1}$ Corruption is like the tip of the iceberg above sea level. ${ }^{2}$ Corruption not only has an impact on the decay of the democratic system and the rule of law, but also damages the joints and structure of people's lives, unfair competition and the persistence of a high-cost economy. ${ }^{3}$ Other literature records that corrupt behavior has indeed been going on since the times of

\footnotetext{
${ }^{1}$ Benny K. Harman, Negeri Mafia Republik Koruptor: Menggugat Peran DPR Reformasi (Yogyakarta: Lamera, 2012), 369.

${ }^{2}$ Bibit S. Rianto, Nurlis E Mueko, Koruptor go to Hell!; Mengupas Anatomi Korupsi di Indonesia (Jakarta: Hikmah, 2009), 26.

${ }^{3}$ Harman, Negeri Mafia, 101.
}

ancient Egypt, Babylon, Rome, the Middle Ages, until now. ${ }^{4}$ As old as the history of human civilization itself.

The research of the two largest mass organizations in Indonesia, Muhammadiyah and Nahdlatul Ulama, determined that corruption was not only a form of disbelief, but an act of shirk, because it made money an ally of God. ${ }^{5}$ Even the problem of corruption in Indonesia is often juxtaposed with major cases such as drugs and terrorism which are often referred to as extraordinary crime and crimes against humanity. ${ }^{6}$ Eradicating

\footnotetext{
${ }^{4}$ M. Ridlwan Nasir, (Ed.), Dialektika Islam dengan Problem Kontemporer (Surabaya: IAIN Press \& LKiS, 2006), 277.

${ }^{5}$ Bambang Widjoyanto, Abdul Malik Gispar, and Laode M. Syarif (ed.), Corruptors are Bambang Widjoyanto, Abdul Malik Gispar, dan Laode M. Syarif (ed.), Koruptor itu Kafir: Telaah Fiqih Korupsi dalam Muhammadiyah dan Nahdlatul Ulama (Jakarta: Mizan, 2010), 19-22.

${ }^{6}$ Harman, Negeri Mafia, 380.
} 
corruption in Indonesia cannot easily ignore its complex cultural dimensions. Something very ironic and worrying. ${ }^{7}$

The enemy of democracy that we are facing is actually not a foreign party who deliberately destroys, undermines and then overthrows democracy. They are none other than members of this nation's family who have the heart to eat the carcass of their own brother: the corruptors. They are destroyers of the foundations of democracy that can destroy and drown the Unitary Republic of Indonesia, not other people. ${ }^{8}$

Even though many corruptors in this country have been imprisoned, new corruptors always emerge as long as the root problems of corruption are not destroyed and are not handled properly. As noted earlier, even though it has succeeded in destroying its surface, new icebergs have appeared again, because under the sea surface there are still larger chunks of ice. The iceberg consists of corruption vulnerability, including (locations, human resources, goods or assets, and activities prone to corruption) and potential problems causing corruption, consisting of poor systems, low moral integrity of officials, irrational remuneration, weak control and a weak lawabiding culture. ${ }^{9}$

Meanwhile, according to the Law of the Republic of Indonesia Number 31 of 1999 concerning Eradication of Corruption, what is meant by corruption is something that is against the law by making acts of enriching oneself or another person or a corporation that can harm the state finances or the country's economy. ${ }^{10}$ AS Hornby stated that someone who commits acts of corruption includes behaving immorally (immoral), depraved (evil deeds), and dishonest (dishonest). ${ }^{11}$ Samuel Huntington in the book Political Order in Changing Societies, defines corruption as the behavior of public officials with deviates from accepted norms in order to serve private ends, the behavior of public officials who deviate from prevailing norms in order to fulfill personal interests. ${ }^{12}$

Corruption is behavior that deviates from the official duties of a state office because of the benefits of personal status or money (individual, close family, own group) or

\footnotetext{
7 Musa Asy'arie, NKRI, Budaya Politik dan Pendidikan (Yogyakarta: LESFI, 2005), 132.

${ }^{8}$ Masdar Hilmy, "Para Perusak Demokrasi", KOMPAS (24 Maret 2017), 7

${ }^{9}$ Rianto, Koruptor go to Hell, 29.

${ }^{10}$ Law of the Republic of Indonesia Number 31 of 1999 concerning Eradication of Corruption Crime, Chapter II, Article 2, Paragraph (1).

${ }^{11}$ Abd. Rachman Assegaf, Filsafat Pendidikan Islam; Paradigma Baru Pendidikan Hadhari Berbasis Integratif-Interkonektif (Jakarta: Rajawali Pers), 332.

12 Samuel Huntington, Political Order in Changing Societies (New Haven and London: Yale University Press, 1968), 59.
}

violates the rules for implementing certain personal behavior. $^{13}$

Corruption is not only a legal issue, but also a social, economic, political, cultural and religious problem. The unbalanced social reality, widespread poverty of the people and inadequate wages and wages received by a worker, the spread of political appetite for power, a culture of shortcuts, and the depoliticization of religion which increasingly denounces faith, all of these have made corruption more fertile and difficult to eradicate, in addition to because many layers of society and components of society are involved in criminal acts of corruption. Therefore, social deconstruction cannot be ignored in order to create a new society that is anticorruption. $^{14}$

In the perspective of Islamic law, corruption is very contrary to the principles of honesty, justice and trust. ${ }^{15}$ Islam, through a number of verses and hadiths, provides serious criticism for corruptors.

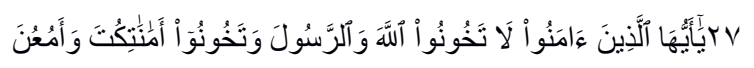

O you who believe, do not betray Allah and Rasul (Muhammad) and (also) do not betray the messages entrusted to you, while you are knowing. ${ }^{16}$

The essence of religious teachings as contained in the AlQur'an and Hadith, apart from being understood and lived, but the most important thing is to be practiced. Religious teachings are not only to be memorized, but to be practiced in earnest. In Islamic law literature there are at least six terms of corruption: ghulul (embezzlement), rishwah (bribery), ghasb (plunder), ikhtilas (pickpocketing), hirabah (robbery), and sariqah (theft). ${ }^{17}$

Education has a strategic role in supporting and even accelerating the formation of a civilized society. ${ }^{18}$ Within the school institution, there are several subjects, including citizenship and religious education, regardless of the school base. For example, in the citizenship subject, it has

\footnotetext{
${ }^{13}$ Robert Klitgaard, Membasmi Korupsi, Cet. II (Jakarta: Yayasan Obor Indonesia, 2001), 31.

${ }^{14}$ Moh. Asror Yusuf (Ed.), 136.

${ }^{15}$ Yunahar Ilyas, et.al., Korupsi dalam Perspektif Agamaagama, Panduan Untuk Pemuka Umat (Yogyakarta: KUTUB, 2011), 27.

${ }^{16}$ QS. Al-Anfal (8): 27. Ministry of Religion of the Republic of Indonesia, Al-Qur'an and Its Translation (Jakarta: Ministry of Religion of the Republic of Indonesia, 2005), 180.

${ }^{17}$ Corruption Eradication Commission, Pandangan Islam terhadap Korupsi: Koruptor, Dunia Akhirat Dihukum (Jakarta: KPK, 2011), 7.

${ }_{18}$ Azyumardi Azra, Paradigma Baru Pendidikan Nasional, Rekonstruksi dan Demokratisasi (Jakarta: Kompas, 2012), xix.
} 
been taught about state defense, good and despicable behavior, not breaking the law, and so on. As well as in religious education, teaching about goodness, the concept of maintaining trust, and so on. However, it is not enough to be a preventive effort for the Indonesian people in the fight against corruption.

Efforts to educate, empower, and raise awareness about how crucial the problem of corruption is, is clearly something that is urgent. ${ }^{19}$ Education should be able to be one of the preventive measures against corrupt behavior from an early age. If the KPK and several other anticorruption agencies succeed in arresting corruptors, then anti-corruption education is also important to prevent the birth of corruptors. Such as the importance of moral and moral lessons in preventing crime, so is anti-corruption education which has important values in preventing acts of corruption.

The facts in the field are that the anti-corruption education material taught in schools and colleges has not yet touched the side of Islamic law, even though Indonesian people are mostly Muslims (Muslims). So, it is felt that it is not comprehensive in touching the religious side of students and students related to corrupt behavior. This results in anti-corruption education that is not maximal in the education process, prevention, let alone eradicating corruption in Indonesia. It is proven that the practice of corruption and criminal acts of corruption is not decreasing day by day, but on the contrary.

Anti-corruption education still focuses as a medium for transferring knowledge (cognitive) only, has not emphasized efforts to build character (affective), and moral awareness in fighting (psychomotor), against corruptive behavior deviations. Anti-corruption education should not only focus on providing insight and understanding, but it is hoped that it can touch on the affective and psychomotor domains, namely shaping anti-corruption attitudes and behaviors in students.

This is where it is important to make new breakthrough in anti-corruption education materials that integrate Islamic law with anti-corruption education in Indonesia. A necessity to integrate the two.

\section{DIRECTION AND PRINCIPLES OF ISLAMIC LAW IN ANTI-CORRUPTION EDUCATION}

In principle, an education process will not achieve the target it wants to achieve if it does not have a clear orientation, even with anti-corruption education. To

${ }^{19}$ Ali Mursyid, Pendidikan Anti-Korupsi Berbasis Masyarakat (Jakarta: Raja Grafindo Persada, 2012), 14. understand the direction of anti-corruption education orientation, as in Law No. 20 of 2003 concerning the National Education System regarding the basis, function, and objectives, which states that: "National education is based on Pancasila and the 1945 Constitution of the Republic of Indonesia." Whereas in article 3 it states:

National education has the function of developing capabilities and shaping dignified national character and civilization in order to educate the nation's life, aiming to develop the potential of students to become human beings who believe and fear God Almighty, have noble character, are healthy, knowledgeable, capable, creative, independent, and become a democratic and responsible citizen.

Whereas in Chapter III Article 4, it is stated that the principles of implementing anti-corruption education are:

1. Education is carried out in a democratic and just manner and is not discriminatory by upholding human rights, religious values, cultural values, and national pluralism.

2. Education is held as a systemic unit with an open system and multiple meanings.

3. Education is held as a lifelong process of cultivating and empowering students.

4. Education is held by modeling, building willingness, and developing the creativity of students in the learning process.

5. Education is held by developing a culture of reading, writing and arithmetic for all members of society.

6. Education is held by empowering all components of society through participation in the implementation and quality control of educational services. $^{20}$

From the law, the direction and orientation of anticorruption education is implicit in the functions, objectives and principles of education delivery. First, basic education, the implementation of anti-corruption education must refer to Pancasila and the 1945 Constitution, because the two bases are ideology, philosophy and source of rules that contain noble values and rules of life as a nation and state. If an Indonesian citizen commits corruption then he is an Indonesian citizen. Because in essence, when he really lives his life based on these two principles, it is impossible for him to commit corruption. Corrupt behavior is an

\footnotetext{
${ }^{20}$ State Secretary of the Republic of Indonesia, Law of the Republic of Indonesia No. 20 of 2003, About the National Education System (Sisdiknas) (Bandung: Citra Umbara, 2010), 56.
} 
extraordinary crime and is incompatible with the values and culture of the Indonesian people.

Second, anti-corruption education function. When an institution can carry out these functions, the essence of the essence of the anti-corruption education process has been fulfilled, namely in the term "shaping character." Character is the essence of the personality of students who must be formed by educational institutions. If this can be formed properly, it will become a very strong foundation when he assumes the mandate and responsibilities assigned to him. Third, the aim of anti-corruption education. The term "having faith and fearing the Almighty God, having noble character, and being a democratic and responsible citizen" is the ideal goal of anti-corruption education. When they commit corruption, it means that they experience a crisis of faith and piety, they have a character that is not commendable because they only care about themselves and their groups.

Fourth, the principle of education. The implementation of anti-corruption education must pay attention to these six principles. So far, many educational institutions do not pay attention to these principles, some of the indications are as follows: This situation is common in society, namely there are several educational institutions that still prioritize the rich over the poor, so indirectly these educational institutions teach ethical ethics. not good for students. This has become a bad habit and must be corrected by educational institutions.

In the delivery of education, open management, especially in the aspects of transparency and financial accountability, has not yet fully occurred in educational institutions. They sometimes only coordinate with school committees and ironically many of the school committees also come from elements of educational institutions. Until now, the author has still not seen any educational institutions that openly make financial transparency through online media, both when he builds and uses funds even though there are very few.

According to Anwar Hamdani, ${ }^{21}$ The direction of anticorruption education orientation can be seen in the general objectives of anti-corruption education, namely: (1) forming knowledge and understanding of forms of corruption and its aspects; (2) changing perceptions and attitudes towards corruption; and (3) forming new skills and skills needed to fight corruption. If referring to Law no. 20 of 2003 concerning the National Education System Article 4 paragraph (3) states that education is held as a lifelong process of cultivating and empowering students. From this basis, the significance of the implementation of

\footnotetext{
${ }^{21}$ Anwar Hamdani, Model Pendidikan Anti Korupsi, 3-4.
}

anti-corruption education through education cannot be ignored its potential as a way to cultivate anti-corruption in Indonesia. $^{22}$

\section{THE AIM OF INTEGRATING ISLAMIC LEGAL VALUES IN ANTI-CORRUPTION EDUCATION}

There are several anti-corruption educational values that can be inferred from the Al-Qur'an surah al-Baqarah verse 188 and Surat an-Nisa 'verse 58. These values are summarized in religious values, namely the value system or moral system which is used as a reference frame be a reference for how to behave physically and spiritually Muslim humans. The values and morality taught by Islam are revelations from God Almighty. which was revealed to the Prophet Muhammad. ${ }^{23}$ In this case, the emphasis is on the attitude and behavior of obeying the teachings of the religion that is followed. In detail, it can be explained as follows:

\section{The Value of Honesty}

The value of honesty is in Surah al-Baqarah verse 188 , namely, "And do not eat some of the assets of some of you in an evil way." The meaning is a prohibition to eat property that is not their right, namely not to eat other people's property in an illegal way because it is not justified by law. Something vanity means not haq. Of course, when taking, possessing, eating, or using improperly, there is an element of lying, cheating, harming others. The opposite of these elements is getting property in a good or honest way.

Honesty is behavior that is based on an effort to make himself a person who can always be trusted in his words, actions and work. The references or characteristics of the value of honesty are honesty, not cheating, sincere, trustworthy, say and act correctly, express something in accordance with reality (don't lie), and have a right intention of every action. In the discussion of this verse we get a very meaningful lesson, how we must be careful in obtaining and using property.

In Surah an-Nisa 'verse 58, Allah commands to fulfill various kinds of mandates that are mandated to anyone who gives the mandate. Honest is one of the characters that is formed from trust. This can be intended as an important element, namely morality. Because the element contained in this verse is the attitude not to abuse the mandate, automatically this element is related to someone's attitude of approval. A Muslim is required to always be in

\footnotetext{
${ }^{22}$ State Secretary of the Republic of Indonesia, Law of the Republic of Indonesia, 5-6.

${ }^{23}$ Abdul Aziz,. Filsafat Pendidikan Islam Sebagai Gagasan. 130.
} 
a state of mind and spirit, including: correctness, speech and deeds. True in all three cases, it will lead to behavior in accordance with the "truth" of the Islamic religion. Islam is a religion that teaches honesty and truth.

One of the characteristics of a righteous person is always telling the truth, keeping promises, carrying out the mandate, and presenting themselves as the real situation. Thus, it is impossible for a righteous person to commit corruption, because in corrupt behavior there must be lies or untruth, either in heart, word or deed. In the Islamic view, the attitude of misappropriation or dishonesty is considered a despicable act which will only lead to munkar and evil. Lies are a trait that tends to justify all means and tends to harm others.

If someone professes faith and love for the Prophet, honesty is the most powerful weapon that adorns the Prophet's life. Honest in speaking, acting, even in thinking is a mirror of personal wholeness, so that it is highly obeyed by his followers and respected by his opponents. Humans, especially Muslims, can imitate these morals. However, honesty is now a rare item both in the world of politics, commerce, and in everyday life.

\section{The Value of Responsibility}

The value of responsibility in surah an-Nisa 'verse 58 is shown in its content that Allah commands to fulfill various kinds of mandates entrusted to anyone who gives the mandate. The characteristic that emerges in this discussion is trust. Someone is said to be trustworthy when that person can be responsible for what is entrusted to him. Responsibility is a person's attitude and behavior to carry out his duties and obligations, which he should do, towards himself, society, the environment (natural, social and cultural), the country and God Almighty.

Characteristics of the value of responsibility, namely the condition of being obliged to bear everything (if something happens, they can be sued, blamed, sued, etc. For example, being brave and ready to accept risks, trusting, not evading, and doing their best), the right to function to accept the burden as a result the attitude of one's own party or other parties, carrying out and completing tasks in earnest.

Often we hear several statements, such as "don't run away from responsibility," "You have to take responsibility for all your actions," or "I ask your responsibility." Responsibility is a duty or obligation to perform or complete a task with full satisfaction (given by someone, or on one's own promise or commitment) which must be fulfilled by someone, and which has a consequent punishment for failure.
It is not easy to be someone who can be trusted by others, especially to maintain the mandate given to us who may be dealing with personal desires which are sometimes inversely proportional to what is mandated. Therefore, maintaining the mandate is seen as the most difficult character to materialize compared to the other characters.

\section{Value of Justice}

The value of justice is found in a cut of the letter an-Nisa 'verse 58, which contains if it is mandated to rule, then carry out the mandate power with full justice. Not only judges must be fair, but all believers must maintain justice in all forms of handling family and social problems. Fair, namely equal weight, impartiality, impartiality / impartiality, partiality / adherence to the truth, rightly, not arbitrarily, balanced, neutral, objective and proportional.

In anti-corruption education, a trustworthy attitude and acting fairly are closely related. One example of mandate is to do justice. When humans have denied justice and do not act fairly in life in this world, it will cause other humans to be sanctified due to the injustice of some humans. The tyranny of some humans by some others, results in suffering, misery for others and excess or space (both property, position and opportunity) for others by their unfair actions, as well as violation of the rights of others against some others (who do unfair or do not hold the mandate).

The value that a person has can express what he prefers. Thus, it can be said that values cause attitudes. Value is a determining factor for attitude formation. However, a person is determined by the amount of value a person has. The goal of value education is the cultivation of noble values in students. To achieve the goals and objectives effectively, various approaches, models and methods can be used in the value education process. It is important to provide variety to the educational process so that it attracts and does not bore students.

These values will only become theoretical knowledge which are only conveyed as subject matter if they are not accompanied and supported by habituation and role models. Things that can maintain knowledge so that it grows into a sense (character) which can then be manifested in behavior (psychomotor), namely the need for the development of spiritual attitudes in children ranging from family to their educational environment. 


\section{INTEGRATION OF ISLAMIC LAW VALUES IN ANTI-CORRUPTION EDUCATION}

Value according to JR Franckel quoted by Chabib Thoha ${ }^{24}$ is "a value is an idea a concept about what some one thinks is important in life." Value is an idea, the concept of what a person thinks is important in life. Then Soeparwoto, et al. in his book explains, value is something that is believed to be true and encourages people to make it happen. In other words, value is a standard of conceptual truth that is believed to be true by individuals or social groups in making decisions about something that is needed as an objective to be achieved..$^{25}$

In addition, value is the determination of a person's stance on how he should act and fight for his goals or objectives. Meanwhile, according to Muhaimin and Abdul Mujib, ${ }^{26}$ expressing value is a determination of the quality of an object involving a type of appreciation or interest. Values can also be interpreted as abstract conceptions in humans or society, about things that are considered good, right, and things that are considered bad and wrong. Value is a set of beliefs or feelings that are believed to be an identity that gives a special style to patterns of thought, feeling, attachments and behavior. ${ }^{27}$

From the various opinions above, it can be concluded that the value in question is something that is believed to be true and can be useful and useful for humans as a reference for behavior. Values can influence a person's feelings, thought patterns and behavior.

\section{Source of Value}

According to Abu Ahmadi and Noor Salimi, ${ }^{28}$ mentioning the source of the value consists of:

a. Divine values which consist of the Koran and the Sunnah. Values derived from the Koran such as the commandments for prayer, zakat, fasting, and hajj as well as values derived from the sunnah, which are obliged to consist of procedures for implementing thaharah and procedures for performing prayers

b. Worldly values consisting of ra'yu (thoughts), customs and natural facts. The value that comes from ra'yu is to provide interpretation

\footnotetext{
${ }^{24}$ Chabib Thoha, Kapita Selekta Pendidikan Islam (Yogyakarta: Pustaka Pelajar, 1996), 60.

${ }^{25}$ Soeparwoto, et al., Psikologi Perkembangan (Semarang: UPT UNNES Press, 2004), 100.

${ }^{26}$ Muhaimin and Abdul Mujib, Pemikiran Pendidikan Islam;

Kajian Filosofis dan Kerangka Dasar Operasionalisasinya

(Bandung: Trigenda Karya, 1993), 91.

${ }^{27}$ Abu Ahmadi and Noor Salimi, Dasar-Dasar Pendidikan

Agama Islam (Jakarta: Bumi Aksara, 1994), 202.

${ }^{28}$ Abu Ahmadi and Noor Salimi, 203.
}

and explanation of the Koran and the sunnah, things that are related to society and are not regulated by the Koran and the sunnah. Values that come from customs, namely communication procedures, human interaction. As well as the value that comes from natural facts, namely the way to dress and eat.

\section{Various Values}

According to Abdul Aziz, ${ }^{29}$ there are at least 3 kinds of values. These values include; logical values, ethical values and religious values. The explanation is as follows:

\section{a. Logical value}

Logical values are values that include knowledge, research, decisions, narrative, discussion, theory, or stories. This value boils down to the truth.

\section{b. Ethical values}

Ethical value is the value of a person or group of people who are composed of a system of values or norms taken from (generalized from) the natural symptoms of the group's society.

\section{c. Religious value.}

Religious value is a value system or moral system which is used as a frame of reference that becomes a reference for how to behave physically and spiritually by Muslim humans. The values and morality taught by Islam are revelations from God Almighty. which was revealed to the Prophet Muhammad.

Added by M. Arifin, ${ }^{30}$ values in Islam contain two categories of meaning, from a normative perspective and from an operative perspective. Value in the normative aspect, namely the consideration of good and bad, right and wrong, haq and ba ,il, blessed and cursed by Allah. From an operative perspective, this value contains 5 categories which are the principles of standardizing human behavior, namely obligatory or fardhu, sunnah or musthab, mubah or jaiz, makruh and haram.

The values according to Abu Ahmadi and Noor Salimi are a set of beliefs or feelings that are believed to be an identity that gives a special style to patterns of thought, feeling, attachment, and behavior. ${ }^{31} \mathrm{As}$ for the definition of anti-corruption education as explained above, anticorruption education is a conscious and planned effort carried out as a cultural correction with the aim of

\footnotetext{
${ }^{29}$ Abdul Aziz, Filsafat Pendidikan Islam Sebagai Gagasan Membangun Pendidikan Islam (Yogyakarta: Teras, 2009), 123132.

${ }^{30}$ M. Arifin, Filsafat Pendidikan Islam (Jakarta: Bumi Aksara, 2000), 140.

${ }^{31}$ Ahmadi, Dasar-Dasar Pendidikan Agama Islam, 667.
} 
introducing a way of thinking and instilling anti-corruption values which include transfer of knowledge (cognitive), efforts to build character (affective), and moral awareness in fighting (psychomotor), against corrupt behavior.

Whether we realize it or not, the implementation of regional autonomy (otoda) has positive implications for community participation. If in the past the role of society was almost absent, then the public space which is now so wide must be maximally utilized by every component of society in supporting the implementation of good and clean governance. Anti-corruption public education is intended as an effort to raise awareness and empower the community so that they have knowledge and abilities, both theoretically and practically in dealing with and following up on allegations of corruption and abuse of power by public officials.

So from that it can be concluded that the values of anticorruption education are something that is believed to be true, in this case, it is about the elements of anti-corruption education, so that it can influence thoughts, feelings, and behaviors that can shape the whole human being. There are a lot of anti-corruption values in Islam, both in the Koran, Hadith and the opinions of experts, as follows:

1. Prohibition of bribes and gifts for officials.

2. Prohibition of phase $>d$ and ghulu $>1$.

3. The need to be honest and trustworthy for leaders or public officials.

4. The necessity to uphold justice and meritocracy.

5. Prohibition of eating haram property and not being greedy for the world.

6. Transparent advice and control over policies.

7. Salary eligibility instructions. ${ }^{32}$

According to the Ministry of Education and Culture, in Agus Wibowo's book, there are values that are internalized in anti-corruption education. ${ }^{33}$

\footnotetext{
32 Sukron Kamil, Pemikiran Politik Islam Tematik (Jakarta: Kencana Prenadamedia Group, 2013), 285-297.

${ }^{33}$ Agus Wibowo, Pendidikan Anti Korupsi di Sekolah; Strategi Internalisasi Pendidikan Anti Korupsi di Sekolah (Yogyakarta: Pustaka Pelajar, 2003), 45-46.
} 
Table 5.1: Reference Values in the Ministry of Education and Culture's Version of Anti-Corruption Education

\begin{tabular}{|c|c|c|}
\hline No. & Score & Description \\
\hline 1. & Honesty & $\begin{array}{l}\text { Behavior that is based on efforts to make himself a person who can always be trusted in words, } \\
\text { actions, and work. }\end{array}$ \\
\hline 2. & Concern & Attitudes and actions that always want to help others and society in need. \\
\hline 3. & Independence & Attitudes and behaviors that are not easily dependent on others in completing tasks. \\
\hline 4. & Discipline & Actions that show orderly behavior and comply with various rules and regulations. \\
\hline 5. & $\begin{array}{l}\text { Responsibility } \\
\text { Answer }\end{array}$ & $\begin{array}{l}\text { Attitudes and behavior of a person to carry out his duties and obligations, which he should do, } \\
\text { towards himself, society, the environment (natural, social and cultural), the country and God } \\
\text { Almighty. }\end{array}$ \\
\hline 6. & Hard work & $\begin{array}{l}\text { Behavior that shows a genuine effort to overcome various obstacles to learning and } \\
\text { assignments and to complete tasks as well as possible. }\end{array}$ \\
\hline 7. & Simplicity & $\begin{array}{l}\text { Being unpretentious, attitudes and behaviors that are not excessive, not many details, not many } \\
\text { knick-knacks, straightforward, what they are, thrifty, as needed, and humble. }\end{array}$ \\
\hline 8. & Bravery & $\begin{array}{l}\text { Have a solid heart and great confidence in the face of dangers, difficulties, and so on. (not } \\
\text { afraid, afraid, scared) and never back down. }\end{array}$ \\
\hline 9. & Justice & $\begin{array}{l}\text { Equal weight, impartiality, impartiality / impartiality, taking sides / holding on to the truth, } \\
\text { rightly, not arbitrarily, balanced, neutral, objective and proportional. }\end{array}$ \\
\hline
\end{tabular}

The translation of these values into various dimensions, namely politics, economics, sociology and law, can be seen as follows:

Table 5.2: Elaboration of Reference Values in Anti-Corruption Education ${ }^{34}$

\begin{tabular}{|c|c|c|}
\hline \multicolumn{3}{|c|}{ ANTI CORRUPTION EDUCATION } \\
\hline No. & Dimensions and Indicators & Reference Value \\
\hline \multirow[t]{2}{*}{1.} & $\begin{array}{l}\text { POLITICAL: } \\
\text { a. Making policies based on public / } \\
\text { shared interests (fair, courageous) }\end{array}$ & $\begin{array}{l}\text { 1. SPORTIVE: chivalrous, honest, upright (still } \\
\text { standing, still upholding justice). }\end{array}$ \\
\hline & $\begin{array}{l}\text { b. Implement policies based on } \\
\text { upholding the truth (honest, brave) } \\
\text { c. Carry out policy oversight in a non- } \\
\text { selective manner (fair, courageous) }\end{array}$ & $\begin{array}{l}\text { 2. RESPONSIBILITY: the condition of being obliged to } \\
\text { bear everything (if anything happens, they can be } \\
\text { prosecuted, blamed, sued, etc. For example, being brave } \\
\text { and ready to accept risks, trusting, not evading, and } \\
\text { doing their best), the right to function accepts the burden } \\
\text { as a result of attitude parties themselves or other parties, } \\
\text { carry out and complete the task in earnest. }\end{array}$ \\
\hline
\end{tabular}

\footnotetext{
${ }^{34}$ Ministry of Education and Culture (Kemendibud), Integrasi Pendidikan Anti Korupsi pada Mata Pelajaran Kewarganegaraan SD/MI Kelas VIII (Jakarta: Ministry of Education and Culture, Directorate General of Basic Education, 2011), 13.
} 


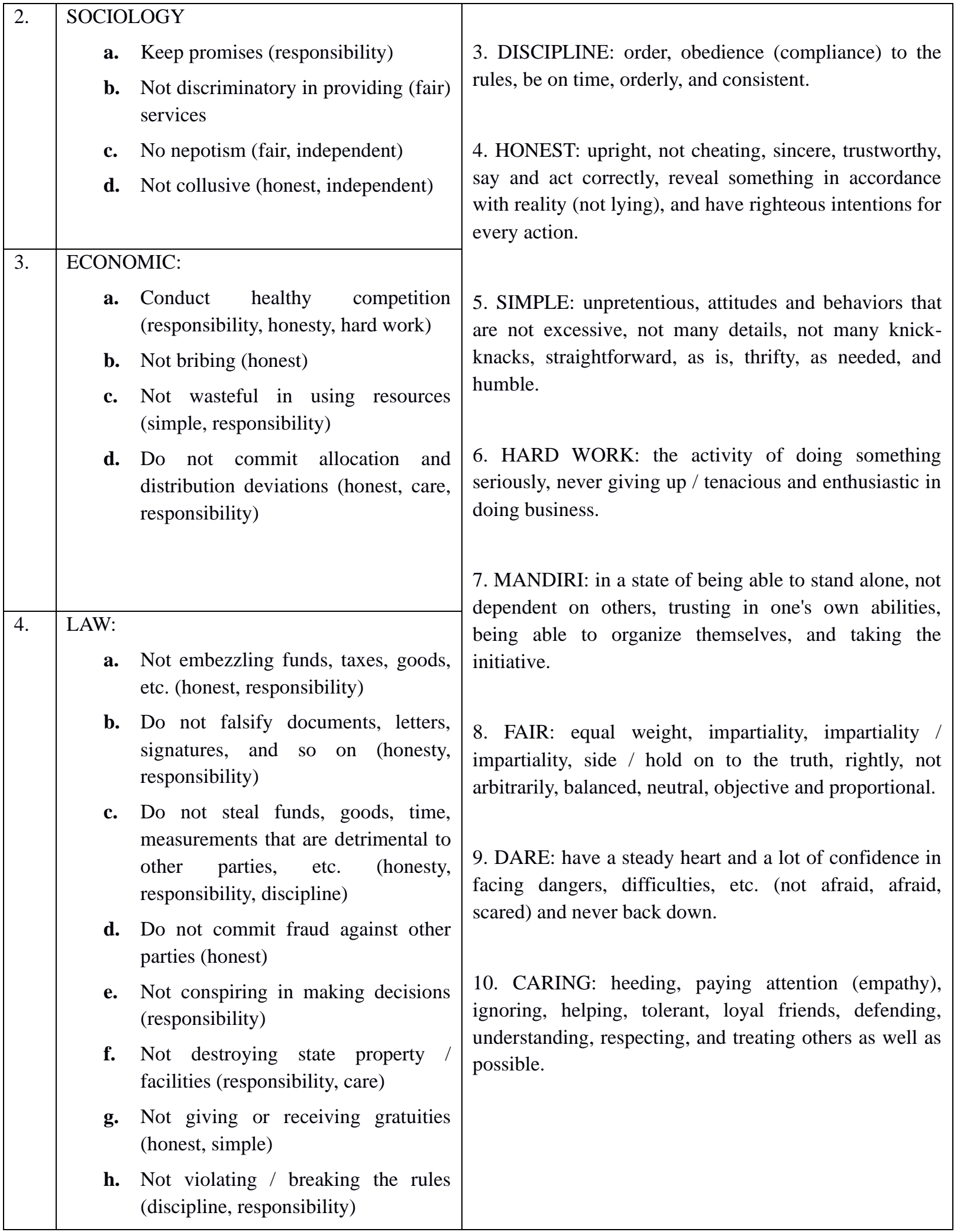

Whereas for educational institutions under the auspices of the Ministry of Religion of the Republic of Indonesia, anticorruption values and behavior references that are integrated into subjects can be identified as follows: 
Table 5.3: Anti-Corruption Values and Behaviors Version by the Director General of Islamic Education, Ministry of Religion of the Republic of Indonesia ${ }^{35}$

\begin{tabular}{|c|c|c|}
\hline No. & $\begin{array}{l}\text { Anti-Corruption } \\
\text { Values and Behaviors }\end{array}$ & $\begin{array}{l}\text { Characteristic features } \\
\text { Anti-Corruption Values and Behaviors }\end{array}$ \\
\hline & $\begin{array}{l}\text { Identify corrupt } \\
\text { behavior to be } \\
\text { avoided. }\end{array}$ & $\begin{array}{l}\text { a. Identify the characteristics of corrupt behavior that need to be } \\
\text { avoided. } \\
\text { b. Accustomed to doing tasks on time } \\
\text { c. Show examples of known cases of corrupt behavior at home, in } \\
\text { madrasah and in the community. } \\
\text { d. Show examples of cases of behavior that do not contain elements of } \\
\text { corruption that have been committed by students. }\end{array}$ \\
\hline 2. & $\begin{array}{l}\text { Be honest, } \\
\text { disciplined, } \\
\text { responsible and fair } \\
\text { in daily life. }\end{array}$ & $\begin{array}{l}\text { a. Dare to put forward something in accordance with the actual } \\
\text { situation. } \\
\text { b. Accustomed to doing things on time. } \\
\text { c. Accustomed to carrying out tasks on time. } \\
\text { d. Accustomed to acting impartially to anyone in taking action }\end{array}$ \\
\hline 3. & $\begin{array}{l}\text { Only receive } \\
\text { something given } \\
\text { according to what is } \\
\text { due. }\end{array}$ & $\begin{array}{l}\text { a. Refusing something that is not in accordance with their rights. } \\
\text { b. Do not want to take something that is not right. }\end{array}$ \\
\hline 4. & $\begin{array}{l}\text { Respect and fulfill the } \\
\text { rights of others }\end{array}$ & $\begin{array}{l}\text { a. Give something to others according to their rights. } \\
\text { b. Never give someone else something that is not their right. }\end{array}$ \\
\hline 5. & $\begin{array}{l}\text { Able to analyze the } \\
\text { causes and effects of } \\
\text { corrupt behavior in } \\
\text { social and state life. }\end{array}$ & $\begin{array}{l}\text { a. Able to identify the causes that encourage the emergence of corrupt } \\
\text { behavior in society and the state. } \\
\text { b. Able to identify the consequences of corrupt behavior in the life of } \\
\text { society and the state. } \\
\text { c. Able to state the reasons for the need to avoid corrupt behavior in } \\
\text { society and the state. }\end{array}$ \\
\hline 6. & $\begin{array}{l}\text { Have a pride in } \\
\text { behaving anti- } \\
\text { corruption. }\end{array}$ & $\begin{array}{l}\text { a. Proud of anti-corruption behavior. } \\
\text { b. Anti against corrupt behavior. }\end{array}$ \\
\hline 7. & $\begin{array}{l}\text { Cultivate anti- } \\
\text { corruption behavior } \\
\text { in the family and } \\
\text { society }\end{array}$ & $\begin{array}{l}\text { a. Disseminate ideas and wishes to avoid corrupt behavior. } \\
\text { b. Demonstrate a commitment to rejecting corrupt behavior. } \\
\text { c. Become an example of anti-corruption behavior. }\end{array}$ \\
\hline
\end{tabular}

\footnotetext{
${ }^{35}$ Ministry of Religion, Guidelines for the Implementation of Anti-Corruption Education, 20-21.
} 


\section{CONCLUSION}

Anti-corruption education is a conscious and planned effort to realize a teaching and learning process that is critical of anti-corruption values. Anti-corruption education is not limited to transfer of knowledge (cognitive), but emphasizes efforts to form character (affective) and moral awareness (morality conciousness) in fighting (psychomotor) against corrupt behavior. In instilling anti-corruption education, there are two patterns, namely: (1) this model puts forward two things; make it an independent course "Anti-Corruption Education", and / or include other courses in the course material. (2) Learning models that emphasize several approaches, such as student center, moral learning, contextual learning, experiential and exemplary approaches, emotional, rational approaches.

The integration of Islamic law in anti-corruption education is an effort to bring closer and closer dialogue between religious and general science, namely as a progressive step to develop certain theories. This can support the formulation of anti-corruption education based on Islamic law to address the problems faced by society and the nation. PTKI and other educational institutions have a major role in encouraging the integration of the two disciplines so that they are not single entities and dichotomous. This can even generate ideas to develop new sciences that are included in Islamic studies, for example anti-corruption fiqh, APBN fiqh, anti-bribery fiqh, to national fiqh.

\section{REFERENCES}

[1] Abu Ahmadi dan Noor Salimi. 1994. Dasar-Dasar Pendidikan Agama Islam. Jakarta: Bumi Aksara

[2] Arifin, M. 2000. Filsafat Pendidikan Islam. Jakarta: Bumi Aksara

[3] Assegaf, Abd. Rachman. 2008. Filsafat Pendidikan Islam; Paradigma Baru Pendidikan Hadhari Berbasis IntegratifInterkonektif. Jakarta: Rajawali Pers

[4] Asy'arie, Musa. 2005. NKRI, Budaya Politik dan Pendidikan. Yogyakarta: LESFI

[5] Aziz, Abdul. 2009. Filsafat Pendidikan Islam Sebagai Gagasan Membangun Pendidikan Islam. Yogyakarta: Teras

[6] Azra, Azyumardi. 2012. Paradigma Baru Pendidikan Nasional, Rekonstruksi dan Demokratisasi. Jakarta: Kompas

[7] Bambang Widjoyanto, Abdul Malik Gispar, dan Laode M. Syarif (ed.). 2010. Koruptor itu Kafir: Telaah Fiqih Korupsi dalam Muhammadiyah dan Nahdlatul Ulama. Jakarta: Mizan

[8] Bibit S. Riantoa and Nurlis E Mueko. 2009. Koruptor go to Hell!; Mengupas Anatomi Korupsi di Indonesia. Jakarta: Hikmah

[9] Departemen Agama RI, Al-Qur'an dan Terjemahnya (Jakarta: Depag RI, 2005), 180.
[10] Harman, Benny K. 2012. Negeri Mafia Republik Koruptor: Menggugat Peran DPR Reformasi. Yogyakarta: Lamera

[11] Hilmy, Masdar. 2017. "Para Perusak Demokrasi", KOMPAS (24 March 2017)

[12] Huntington, Samuel. 1968. Political Order in Changing Societies. New Haven and London: Yale University Press

[13] Kamil, Sukron. 2013. Pemikiran Politik Islam Tematik. Jakarta: Kencana Prenadamedia Group

[14] Klitgaard, Robert. 2001. Membasmi Korupsi, Cet. II. Jakarta: Yayasan Obor Indonesia

[15] Komisi Pemberantasan Korupsi. 2011. Pandangan Islam terhadap Korupsi: Koruptor, Dunia Akhirat Dihukum. Jakarta: KPK

[16] Law of the Republic of Indonesia Number 31 of 1999 concerning Eradication of Corruption Crime, Chapter II, Article 2, Paragraph (1).

[17] Ministry of Education and Culture (Kemendibud). 2011. Integrasi Pendidikan Anti Korupsi pada Mata Pelajaran Kewarganegaraan SD/MI Kelas VIII (Jakarta: Ministry of Education and Culture

[18] Muhaimin dan Abdul Mujib. 1993. Pemikiran Pendidikan Islam; Kajian Filosofis dan Kerangka Dasar Operasionalisasinya. Bandung: Trigenda Karya

[19] Mursyid, Ali. 2012. Pendidikan Anti-Korupsi Berbasis Masyarakat. Jakarta: RajaGrafindo Persada

[20] Nasir, M. Ridlwan (Ed.). 2006. Dialektika Islam dengan Problem Kontemporer. Surabaya: IAIN Press \& LKiS

[21] Soeparwoto, et all. 2004. Psikologi Perkembangan. Semarang: UPT UNNES Press

[22] State Secretary of the Republic of Indonesia. 2010. Law of the Republic of Indonesia No. 20 of 2003, concerning the National Education System (Sisdiknas). Bandung: Citra Umbara

[23] Thoha, Chabib. 1996. Kapita Selekta Pendidikan Islam. Yogyakarta: Pustaka Pelajar

[24] Wibowo, Agus. 2003. Pendidikan Anti Korupsi di Sekolah; Strategi Internalisasi Pendidikan Anti Korupsi di Sekolah . Yogyakarta: Pustaka Pelajar

[25] Yunahar Ilyas, et.al.. 2011. Korupsi dalam Perspektif Agama- agama, Panduan Untuk Pemuka Umat. Yogyakarta: Kutub 